\title{
MONITORING STUDIES OF UNIVERSITY GRADUATES' SATISFACTION WITH THE QUALITY OF EDUCATION: THE MAIN APPROACHES
}

\author{
MONITORAMENTO DOS ESTUDOS DE SATISFAÇÃO DE UNIVERSITÁRIOS \\ GRADUADOS QUANTO À QUALIDADE DA EDUCAÇÃO: AS PRINCIPAIS \\ ABORDAGENS
}

\author{
ESTUDIOS DE SEGUIMIENTO DE LA SATISFACCIÓN DE LOS GRADUADOS \\ UNIVERSITARIOS CON LA CALIDAD DE LA EDUCACIÓN: LOS PRINCIPALES \\ ENFOQUES
}

\author{
Irina Semenovna AVRAMKOVA ${ }^{1}$ \\ Natalya I. ANUFRIEVA ${ }^{2}$ \\ Alexander Vladlenovich KAMYANETS ${ }^{3}$ \\ Elena Olegovna KUZNETSOVA ${ }^{4}$ \\ Anna I. SCHERBAKOVA ${ }^{5}$
}

\begin{abstract}
The article actualizes the problem of monitoring the qualitative indicators of higher education in modern Russian universities. The opportunities of monitoring to identify the levels of university graduates' satisfaction with the obtained education, considering the rapidly changing socio-cultural and economic conditions are disclosed. Substantiation of heuristic possibilities for monitoring the quality of higher education in accordance with the social demand. At the basis of the study methodology lies the systemic approach allowing the authors to conduct a comprehensive analysis of the specific features of monitoring. The analysis, generalization, and classification of the main indicators constituting the foundation for the study of university graduates' satisfaction with the quality of education are conducted. The article presents the results of this monitoring and proposes a classification of methodological and methodical approaches to the study of the topic. Scientific novelty. The topic of monitoring university graduates' satisfaction with the quality of education allows the authors to explore the main relevant problems of modern universities and disclose the potential of higher education. The acquired study results can be used in further research, scientific and methodical developments, and project activity aimed at improving students' satisfaction with the educational process and promote the quality of pedagogical work.
\end{abstract}

KEYWORDS: Education. Monitoring. Education quality. University graduates. Satisfaction with education.

\footnotetext{
${ }^{1}$ Russian State Pedagogical University (HERZEN), Saint Petersburg - Russia. Dr. Head of the Department of Musical and Instrumental Training, Director of the Institute of Music, Theatre and Choreography. ORCID: https://orcid.org/0000-0002-3693-9605. E-mail: avramkova@gmail.com

${ }^{2}$ Russian State Social University (RGSU), Moscow - Russia. Dr. Professor. ORCID: https://orcid.org/00000003-4119-9805. E-mail: nata415485@mail.ru

${ }^{3}$ Russian State Social University (RGSU), Moscow - Russia. Dr. Professor. ORCID: https://orcid.org/00000003-3558-7035. E-mail: kamenez.a@rambler.ru

${ }^{4}$ Russian State Pedagogical University (HERZEN), Saint Petersburg - Russia. Professor of the Department of Musical and Tool Preparation. ORCID: https://orcid.org/0000-0001-6301-8898. E-mail: kyznetsova65@mail.ru

5 Schnittke Moscow State Institute of Music (MSIM), Moscow - Russia. Dr. Professor. ORCID: https://orcid.org/0000-0001-7371-7211. E-mail: anna.68@list.ru
}

RPGE- Revista on line de Política e Gestão Educacional, Araraquara, v. 25, n. esp. 1, p. 638-653, mar. $2021 . \quad$ e-ISSN:1519-9029 DOI: https://doi.org/10.22633/rpge.v25iesp.1.15004 
RESUMO: O artigo atualiza o problema do monitoramento dos indicadores qualitativos do ensino superior nas modernas universidades russas. São divulgadas as oportunidades de monitoramento para identificar os níveis de satisfação dos graduados universitários com a educação obtida, considerando as condições socioculturais e econômicas em rápida mudança. Tem por objetivo a comprovação das possibilidades heurísticas de monitoramento da qualidade do ensino superior de acordo com a demanda social. Na base da metodologia de estudo está a abordagem sistêmica que permite aos autores conduzir uma análise abrangente das características específicas do monitoramento. A análise, generalização e classificação dos principais indicadores que constituem a base para o estudo da satisfação dos graduados universitários com a qualidade do ensino são conduzidos. $O$ artigo apresenta os resultados dos estudos de monitoramento e propõe uma classificação das abordagens metodológicas e metódicas para o estudo do tema. Novidade científica. O tema do monitoramento da satisfação dos graduados universitários com a qualidade do ensino permite aos autores explorar os principais problemas relevantes das universidades modernas e divulgar o potencial do ensino superior. Os resultados adquiridos no estudo podem ser utilizados em pesquisas posteriores, desenvolvimentos cientificos e metodológicos e atividades de projeto que visem melhorar a satisfação dos estudantes com o processo educacional e promover a qualidade do trabalho pedagógico.

PALAVRAS-CHAVE: Educação. Monitoramento. Qualidade da educação. Graduados universitários. Satisfação com a educação.

RESUMEN: El artículo actualiza el problema del seguimiento de los indicadores cualitativos de la educación superior en las universidades rusas modernas. Se divulgan las oportunidades de monitoreo para identificar los niveles de satisfacción de los egresados universitarios con la educación obtenida considerando las condiciones socioculturales y económicas rápidamente cambiantes. Fundamentar las posibilidades heurísticas para monitorear la calidad de la educación superior de acuerdo con la demanda social. En la base de la metodología del estudio se encuentra el enfoque sistémico que permite a los autores realizar un análisis integral de las características especificas del seguimiento. Se realiza el análisis, generalización y clasificación de los principales indicadores que constituyen la base del estudio de la satisfacción de los egresados universitarios con la calidad de la educación. El artículo presenta los resultados de estudios de seguimiento y propone una clasificación de enfoques metodológicos y metódicos para el estudio del tema. Novedad cientifica. El tema del monitoreo de la satisfacción de los graduados universitarios con la calidad de la educación permite a los autores explorar los principales problemas relevantes de las universidades modernas y revelar el potencial de la educación superior. Los resultados del estudio adquiridos se pueden utilizar en futuras investigaciones, desarrollos cientificos y metódicos y actividades de proyectos destinadas a mejorar la satisfacción de los estudiantes con el proceso educativo y promover la calidad del trabajo pedagógico.

PALABRAS CLAVE: Educación. Seguimiento. Calidad de la educación. Titulados universitarios. Satisfacción con la educación. 


\section{Introduction}

The increased significance of monitoring the study of university graduates' satisfaction with the quality of education is primarily associated with the relevant problems of the modern university educational process. These problems include the training in outdated specialties not demanded in the modern labor market in many universities; the commercialization of higher education presenting a barrier for the representatives of social strata unable to pay for the provided educational services; the interest in the very fact of obtaining a higher education diploma instead of the real interest in the process of learning; the decline in the popularity of productive labor and research activities, as well as socially significant activity (IAO, 2009).

The evaluation of the importance of these problems will not be fully objective if it is only associated with the opinions of certain experts and specialists in the field of higher education. The evaluation of the activity of universities by graduates as the main consumers of educational services is no less important. Therefore, the quality of higher education is viewed as a combination of the quality of the provided products in the form of obtained knowledge and graduates' satisfaction with these products.

The study of the results of the said combination through monitoring is currently most often carried out according to the following main indicators: the level of the content of education, the level of educational technologies, qualification of teachers, the level of the material and technical base, university research activity, the equipment of the educational process with scientific and methodical literature, the level of information technologies, scientific and production practice, the balance of curricula and timetables of the educational process, and the employment of graduates (KISELEVA, 2016).

\section{Literature review}

In a broad sense, monitoring means a specially organized systematic observation of the state of objects, phenomena, and processes with the goal of their evaluation, control, and prognostication. In the context of the substantiation of the opportunities for monitoring in the study of higher education quality, studies of applicants' motivation in choosing a university in comparison with university graduates' satisfaction with the obtained education present special interest. These studies identify the most popular preferences of students, such as the high quality of educational services, the presence of the desired specialty and budget-funded positions in it in a university, successful employment, as well as the positive image of a 
university (MILIAEVA, 2016). The main requirements for monitoring include the continuity, interconnection, and interdependence of the higher education quality indicators. Moreover, it is especially emphasized that under the condition of the increasing popularity of distance learning the needs and demands of students themselves and not the employer come into the foreground compared to classical university education (Golyshev, 2006). Following this approach, the following requirements to the quality of education posed by university graduates are identified:

- professional competence of the teaching staff;

- the ability of the teaching staff to maintain the necessary level of communicative culture and meaningful communication between teachers and students within the student environment;

- teachers' concernment with the students obtaining knowledge;

- the level of organization of practical lessons;

- the modern level of teaching primarily in the aspect of content;

- the connection between education and the socio-cultural and economic reality (POGREBITSKAIA, 2005).

Researchers highlight the importance of organizing the monitoring of satisfaction with education not only among graduates but also students of all courses as a systemic research procedure. In this case, the opportunity emerges for a more meaningful interpretation of the attitude towards education of those who have received higher education. In accordance with this research approach, such monitoring has to assess the following (VASILEVA, 2008; VOLOVSKAIA; PLIUSNINA, 2015):

- quality of first-year applicants' (students) preparation to study at a university;

- the qualities of 3rd- and 4th-year students;

- the qualities of graduates;

- motivation for learning in students and graduates;

- social competence of students and graduates;

- the professional and personal potential of graduates;

- the terminal values of students and graduates;

- students' and graduates' satisfaction with the quality of the educational process at the university;

- the employer's satisfaction with the quality of graduates' training; 
- demand for graduates in the labor market.

\section{Methods}

The research methodology was based on the characteristics of the quality of education that can be expressed in certain quantitative indicators (UPRAVLENIE KACHESTVOM PODGOTOVK, 2008; FATKULIN, 2007; FILIPPOVA, 2007). These measurable characteristics include the traditional quantitative assessments of the level of the obtained knowledge, quantitative indicators of the demand for graduates in the labor market, and students' degree of satisfaction with training. Moreover, researchers note that "the quality of education does not equal the quality of training but reflects an individual's readiness and ability to be in demand in the labor market, successful in professional activity, and capable of self-realization" (BOLOTOV; EFREMOVA, 2007, P. 92).

In studies of the quality of modern higher education, the heuristic opportunities for monitoring are viewed as sufficient under the condition of the study of the entire educational process at a university including a range of corresponding research procedures and types of work (BOLOTOV; EFREMOVA, 2007). In this process, the foundation for ensuring the quality of higher education should already be established at the stage of a university working with schools through vocational guidance activities, meetings of university teachers with school students, and studying the requests of high school students related to the possibility of obtaining a particular higher education.

The quality of higher education also depends on the quality of admission campaigns that present the opportunity to establish trusting contacts with applicants and conduct the necessary presentations, consultations, and conversations with them. Work with schools and applicants should include the continuous monitoring of educational interests of the potential contingent of university students and the identification of the appropriate additional resources to improve the quality of university education.

Another monitoring topic related to the quality of education is a systematic analysis of the results of entrance examinations and the study of personal characteristics and the level and nature of educational and cognitive needs and knowledge. Comprehensive monitoring of university education quality involves the study of the results of the ongoing monitoring of students' academic achievements, as well as monitoring surveys of students on the recent results of exam sessions including students' satisfaction with the obtained knowledge, the conditions of the educational process, the control system, etc. Each of these monitoring types 
can include the opportunity to use various grading systems allowing one to evaluate both the quality of certain educational process parameters and the level of students' satisfaction with them.

One of the least developed research aspects in the study of education quality is the study of universities' educational and methodical literature. This issue is especially relevant in humanitarian education in which the criteria for the evaluation of publishing products for universities that have to include not only the evaluations of education experts but also the opinions of students on the educational literature they study remain quite vague.

It is also noted that it is necessary to preserve the effective traditions of the classical education model and shift the teachers' focus "from the transfer of information on the content of the academic discipline to the active interaction with students, the creation of conditions for their motivation to independently search and master the necessary information" (BOBROVA, 2018, p. 130).

Of equal importance is the continuous monitoring of the quality of teaching in universities, the decisive role in which is played by student surveys. By no coincidence monitoring studies of university graduates' satisfaction demonstrate that this indicator was noted by the respondents as one of the most important in the assessment of the university in question.

Another important indicator for monitoring studies resides in studying the quality of final qualification works (their topics, problems, scientific level, etc.). At present, this evaluation is primarily carried out by university teachers themselves. On the other hand, there is a lack of independent expertise the purpose of which could lie not so much in strengthening the administrative control over the teaching staff as in identifying the main problems in the quality of final qualification works and providing the necessary assistance in improving this process including the creation of optimal conditions for the work of scientific advisors and graduating students (for instance, a thoughtful distribution of workload among the teachers who work as students' scientific advisers preventing them from work overload affecting the quality of final qualification works).

A special group of problems in the quality of higher education is associated with the demand for university graduates among employers. Monitoring studies on this topic can be effective under the condition that the contact with employers interested in university graduates is maintained throughout the process of students' learning at the university. The study of the experience of certain universities in this direction demonstrates that the types of such contacts can be quite diverse. Said types include systematically held meetings of 
students with potential employers, effective educational and production practice based on institutions that can provide jobs for university graduates, practice-oriented training of students corresponding to the profile of production activity in the employing organizations, etc.

Continuous monitoring of such career guidance work of a university contributes to its constant improvement and development. The diversification of the forms of students' participation in the educational and production practice allowing their active participation in the general production process, the creation of independent creative projects, in planning and organizing the activities of a potential employer, etc., is especially critical.

No less important is the involvement of students in research and creative search activities which can also become the object of corresponding monitoring studies (ALESHKOVSKII; GASPARISHVILI; KRUKHMALOVA, 2019).

All the aforementioned areas of educational and production activities of students can be implemented under the condition of the creation of a corresponding information base for the accumulation of data and necessary indicators of each direction of students' training. The implementation of modern information and computer technologies can ensure corresponding automatic monitoring of many indicators of such work.

In this case, a higher education institution becomes a self-sufficient educational and production association capable of development and constant self-improvement accounting for the changing socio-cultural and economic situation, the transforming labor market conditions, and the needs and demands of the student audience in the field of education.

The results of the conducted monitorings of satisfaction in university students and graduates demonstrate that the choice of profession is most strongly affected by the opportunities for self-disclosure, self-realization, the realization of one's abilities, social recognition, and the opportunity to provide for oneself and one's family (MISHCHENKO, 2016). This fact allows posing the appropriate requirements for higher education where special attention should be paid to studying students' creative potential, involving them in educational and production activities, and stimulating the timely mastery of professional skills that will subsequently be demanded in the labor market.

The realization of these requirements crucial for graduates' satisfaction with the educational process is feasible if an appropriate psychological atmosphere of goodwill and mutual respect manifesting in ensuring the freedom in expressing one's opinions, establishing positive informal interpersonal relationships outside of educational activities, the satisfaction of the relationship between teachers and university administration, encouraging creativity and 
initiative, and teachers' concern to improve the conditions for educational activities is formed in the educational environment (MISHCHENKO, 2016).

It is highlighted that the creation of such an educational environment primarily depends on the effectiveness of the educational work at a university interconnected with the satisfaction of students' educational needs. In this regard, researchers distinguish the following psychological types of students - the productive, reproductive, and passiveconsumer types of students in the context of satisfaction of educational and cognitive interests. It is the first two types who are most satisfied with their higher education (POMELNIKOVA, 2017).

Some researchers view students' and graduates' satisfaction with higher education as the indicator of university education overall. Accordingly, the following main factors determining the quality of university education are identified (ELISEEVA, 2013; RUSANOVA, 2005):

1. The quality of the subject receiving educational services;

2. The quality of the object providing educational services:

- the quality of university education management;

- the quality of project activity in the sphere of education (structure, content, training programs);

- the quality of resource support for the provision of educational services (material and technical, methodological, personnel, etc.);

3. The quality of the process of providing educational services:

- the quality of the organization and implementation of the applied technologies for the provision of educational services (the structure of the interaction between its subjects, the form and content of the educational process, motivational factors);

- the quality of the control of the process of providing educational services;

- the quality of the control of the results of providing educational services.

An important place in studying the quality of education in certain universities through monitoring is occupied by studying the planning and organization of the educational process including the identification of the degree of realization of the curricula, the correspondence of the studied topics to the existing curricula, compliance with the established academic 
schedules, implementation of the adopted managerial decisions, the level of knowledge obtained by students, and the state of the material and technical base (SHLYKOV, 2008).

Graduate surveys demonstrate that these issues draw their attention as well.

Universities themselves also join in the process of studying the level of customer satisfaction with the quality of specialist training involving the existence of their own service for monitoring the quality of training of their students, a university system for the evaluation of the provided education, the evaluation of the longevity of interaction with educational service consumers, and business contacts of the university with organizations interested in the university graduates.

Of some importance for the evaluation of the quality of higher education through monitoring studies among university graduates can be the studies of the relation between graduates' career aspirations and the degree of their satisfaction with the obtained education (GALEEVA, 2007). One of such studies shows that

the highest satisfaction with their professional activity $(41.5 \%)$ is observed in the respondents demonstrating a high orientation towards a career while among the respondents with the low degree of such an orientation the proportion of satisfied individuals does not exceed $13 \%$. Orientation towards career presents a strong intrinsic motivation in the career process subjects. The higher it is, the more success the graduates objectively achieve. Hence, their subjective satisfaction with their achievements is also higher (DIDKOVSKAIA, 2015, p. 67).

\section{Results and discussion}

Monitoring studies end up being not just a research procedure accompanying the educational process on all of its stages and in various aspects but an instrument for the formation of an interactive educational space including teachers, students, and administration as its participants. A special educational environment is created in the center of which is the student themself with their educational and extracurricular requests significant for solving educational problems.

In this case, the possibilities of a university as an independent educational and production association capable of creating and occupying their own jobs that are of public importance are also expanding.

At present, universal approaches to the evaluation of university graduates' satisfaction with education are lacking. Nonetheless, the theoretical approach based on the fixation of confirmation/non-confirmation in accordance with which the expectations or requirements of 
graduates are compared with the perception of the provided educational services or the obtained education in general remains the most popular one. Moreover, if graduates receive the expected result from the university, their satisfaction with the quality of education approaches zero since the received educational services are taken for granted. Accordingly, graduates experience dissatisfaction in the absence of expected results. If a graduate receives more than expected, there is a clear satisfaction with the quality of the obtained education.

A special problem is presented by graduates' satisfaction with scientific research activity at universities. Certain monitoring studies identify the following corresponding requirements of respondents: provision of an increased scholarship to students actively involved in research activities; cooperation of the university with foreign educational institutions in conducting research (ERMAKOVA; NIKULINA, 2017).

Many surveyed university graduates stress the need for additional advanced training of students in the educational process in accordance with the professional specialization demanded in the labor market. The studied profile disciplines which should be taught in such a way that no special retraining of graduates is required following the demands of employers are evaluated in the same aspect. In accordance with this requirement, employers should participate more actively in the educational process (ERMAKOVA; NIKULINA, 2017).

The requirements of employers for a sufficient professional level of graduates also manifest in their predominant interest in masters compared to bachelors, as well as in additional professional training of graduates with higher education (ARTAMONOVA, 2008; SUSHCHENKO; KUZNETSOV; PECHENKINA, 2019).

One of the most critical problems of higher education is the lack of effective feedback mechanisms in the educational process. On the one hand, the systems for monitoring educational activities are improved through modern information technologies. On the other hand, the possibilities for a qualitative analysis of students' mastery of knowledge accounting for their individual psychological and sociocultural characteristics are not fully used.

In solving this problem, it is fundamental to choose pedagogical strategies in favor of students thus ensuring their real personal development and professional training sufficient for them to be demanded in the labor market and pursue their professional career in real society.

One of the essential features of the corresponding personality-oriented university pedagogy is, in this case, the implementation of continuous monitoring of graduates' satisfaction with the quality of training in educational programs. Along with pedagogical procedures, this research procedure has its own ethical aspects related to observing students' right to express their requests and interests in relation to the content and technology of the 
acquired knowledge which are of vital importance for both their professional and personal growth.

Following this objective, it is necessary to identify two types of criteria -subjective and objective. The first type refers to criteria in which students' satisfaction manifests in the corresponding statements, evaluations, and verdicts. The second type includes the criteria that can show themselves in graduates' real academic behavior in the process of obtaining professional education: their academic performance, attendance, and participation in social work as the completed educational tasks (BORDOVSKII, 2008).

Meanwhile, it is important to establish the correlations between the two groups of criteria or lack thereof. In the latter case, such a finding can be evident of the existing discrepancies between the internal attitudes of students in relation to learning and the demonstration of their educational activity.

Favorable, unfavorable, or indifferent relations between students and teachers which have developed in the educational process and create a certain socio-psychological background important for the formation of a sense of satisfaction with training in educational programs can be identified as a separate group of criteria.

Planning of the monitoring of student satisfaction with the quality of educational training should be carried out in three groups of students: those with excellent academic performance, those with academic performance with predominantly good grades, and those with satisfactory academic performance. Each of these groups has its own set of attitudes and relations regarding the educational process which manifest themselves in the corresponding interest in obtaining professional knowledge, as well as a set of their own educational problems.

In accordance with the monitoring requirements, it also appears necessary to allocate separate study groups indicative of the entire educational process for possible continuous observation in the future instead of the entire set of students.

The very nature of monitoring indicators has to be interdisciplinary to be applied to any area of professional training. In this regard, both the survey method (questionnaires, interviews of experts from among the presidents of groups and student community leaders) and the method of studying educational documentation (academic performance) to reveal the real picture of the level of student satisfaction with educational programs have proved themselves effective.

The experience of conducting monitoring studies in universities shows that it is desirable to conduct them in three stages. The first stage (pilot) typically includes the 
development of research methods and their approbation on a limited sample of subjects. The second stage presents the monitoring itself; the third stage includes processing and analyzing the obtained data. Accordingly, it is advisable to carry out monitoring based on a sample population representative of the general contingent of university graduates.

This objective can be fulfilled through the preparation of expert conclusions, methodological recommendations, scientific reports, and scientific publications based on the monitoring results. The deployed monitoring technologies and instruments can serve in organizing and managing the educational process at a university and increasing the effectiveness of educational programs.

The obtained results can also constitute the problem field necessary for further research, scientific and methodological developments, and project activities aimed at increasing student satisfaction with the educational process and improving the quality of pedagogical work.

Monitoring research can contribute to the development of scientific and methodological approaches to identifying graduates' satisfaction with the quality of training in educational programs among which the most attention should be paid to the axiological and person-centered approaches to the educational process on the part of teachers and students.

The analysis of monitorings carried out in universities shows that important areas of monitoring research include conducting factor analysis of the system of students' orientations and interests essential for their satisfaction with educational programs, as well as of students' personality types that influence their attitudes towards the educational process using computer diagnostics.

A special issue of monitoring studies is the development of the "mediator language" between students' satisfaction with educational programs expressed in the appropriate verbal form and the professional language of the educational process and educational programs. The development of such a language allows for the implementation of the obtained results in the real organization of educational activities.

The existing concepts and technologies for monitoring graduates' satisfaction with the quality of training in educational programs allow developing a strategy for increasing the level of students' satisfaction with educational programs. This strategy involves accounting for both educational and extracurricular factors affecting the quality of education which can be identified in the course of monitoring.

The developed monitoring instruments are typically used both by teachers and researchers of the educational process. The obtained monitoring study results can then be 
accounted for in preparing teachers for training sessions and developing educational and methodological materials and educational content contributing to maintaining a high level of students' interest in obtaining professional knowledge. With certain modifications, the monitoring instruments can also be used to study satisfaction with educational programs in students of all years.

\section{Conclusion}

The study of the results of monitoring studies shows that the general and specific satisfaction of graduates with their educational activities can be identified. Specific satisfaction refers to the degree of realization of one's individual interests in the educational process. General satisfaction is associated with whether one's expectations from the chosen future profession, specialty, and status as a graduate of a particular university are met.

We can also conclude on the need to carry out university management focused on the correspondence of the educational process to the qualification characteristics of the obtained profession, as well as on determining the appropriate optimal amount of study time, constant improvement of the level of pedagogical skills of university teachers, and strengthening the material and technical base of the university.

A promising direction for further research on students' satisfaction with university education is the creation of socio-typical portraits of the representatives of a certain level of student satisfaction with education proposed by some researchers.

In solving the problem of students' satisfaction with their education, it is advisable to pay increased attention to their socialization including such stages as an introduction to the specialty, adaptation to the educational activity, and consolidating and improving the previously formed positive attitude towards the various aspects of life at a university.

The need to ensure the close interaction of educational, methodological, and scientific work in universities with appropriate wide material and technical base is also emphasized. Students' satisfaction with their education should also be supported by appropriate scientific forecasting and programming of the quality of the entire educational process in the long-term perspective.

Different significant indicators of satisfaction with education are identified in different universities depending on the specifics of the problems of a given educational institution. The most important indicators include the ratio of the price and quality of education, the state of the scientific and technical base of the university (provision of educational equipment, a 
library, teaching aids, etc.), satisfaction with additional education (advanced training programs, professional training, scientific circles, sections, etc.), employment opportunity after graduation, the organization of students' research work, and social conditions and the socio-psychological climate.

The integrality and adequacy of higher education quality evaluation through the means of monitoring among university graduates largely depends on the realization of the complex approach in studying the activity of universities involving the interrelation of various research procedures and all the studied educational process components.

ACKNOWLEDGMENTS: The publication was prepared as a part of research work on the topic "Monitoring of graduates' satisfaction with the quality of training in educational programs" according to the order of the Russian State Social University No. 530 of April 4, 2020 "On the realization of internal research works at the expense of the Russian State Social University".

\section{REFERENCES}

\section{ALESHKOVSKII, I. A.; GASPARISHVILI, A.G.; KRUKHMALOVA, O.V. Opyt} sotsiologicheskogo analiza sistemy obrazovaniia regiona Rossii na primere Kemerovskoi oblasti [Experience of sociological analysis of the education system of a region of Russia on the example of the Kemerovo region]. Moscow: MAKS Press, 2019.

ARTAMONOVA, M.V. Reforma vysshei shkoly i Bolonskii protsess v Rossii [Higher education reform and the Bologna Process in Russia]. Moscow: Economics, 2008.

BOBROVA, T. A. Sovremennaia sistema vysshego obrazovaniia Rossiiskoi Federatsii: osnovnye problemy i puti ikh resheniia [Modern system of higher education in the Russian Federation: the main problems and the ways to solve them]. Molodoi Uchenyi, v. 45, n. 231, p. 127-130, 2018.

BOLOTOV, V. A., EFREMOVA, N. F. Sistema otsenki kachestva obrazovaniia: Uchebnoe posobie [The system for assessing the quality of education: Study guide]. Moscow: Logos, 2007.

BORDOVSKII, G. A. Modeli i metody vnutrennego i vneshnego otsenivaniia kachestva obrazovaniia v vuzakh [Models and methods of internal and external assessment of the quality of education in universities]. Saint Petersburg: "Knizhnyi dom" LLC, 2008.

DIDKOVSKAIA, I. A. V. Uspeshnost professionalnoi karery molodezhi v transformiruiushchemsia obshchestve [Youth's professional career success in the transforming society]. Sotsiologicheskie Nauki, n. 96, p. 64-68, 2015. 
ELISEEVA, E. N. Otsenka udovletvorennosti potrebitelei obrazovatelnykh uslug na fakultete upravleniia [Assessment of satisfaction of consumers of educational services at the Faculty of Management]. Bulletin of the Chelyabinsk State University, v. 3, n. 294, p. 107-110, 2013.

ERMAKOVA, Z. H. A.; NIKULINA, I. U. N. Kachestvo obrazovaniia s pozitsii potrebitelei obrazovatelnykh uslug vuza [The quality of education from the perspective of consumers of educational services of a university]. Creative Economy, v. 11, n. 7, p. 726-735, 2017.

FATKULIN, A. A. Sovremennoe obrazovanie: upravlenie, kachestvo, innovatsii: Uchebnoe posobie [Modern education: management, quality, innovation: study guide]. Vladivostok: Publishing house of the Far Eastern State Technical University, 2007.

FILIPPOVA, I. V. Monitoring udovletvorennosti potrebitelei kachestvom podgotovki spetsialistov v Mordovskom gosudarstvennom universitete [Monitoring of consumer satisfaction with the quality of training of specialists in the Mordovian State University]. Mordovia University Bulletin, 1 Series "Economic Sciences”, p. 21-23, 2007.

GALEEVA, R. B. Marketingovye issledovaniia v obrazovanii: monografiia [Marketing research in education: monograph]. Moscow: Dashkov and K, 2007.

GOLYSHEV, I. G. Upravlenie kachestvom obrazovaniwa v vuze: poisk modeli [Education quality management in a university: the search for a model]. Cheboksary: Novoe Vremia, 2006.

IAO, L. M. Problemy vysshego obrazovaniia v sovremennom rossiiskom obshchestve [Problems of higher education in modern Russian society]. Modern problems of science and education. Penza: “Akademiia Estestvoznaniia” Publishing House, 2009.

KISELEVA, M. V. Vovlechenie obuchaiushchikhsia vuza $v$ otsenku i povyshenie kachestva obrazovaniia [Involvement of university students in the assessment and improvement of the quality of education]. Vestnik of Kostroma State University, Series: Pedagogy. Psychology, Sociokinetics, n. 22, p. 142-147, 2016.

MILIAEVA, L. G. Analiz uspeshnosti trudoustroistva vypusknikov vuzov v usloviiakh kompetentnostnogo podkhoda [Analysis of the success of the employment of university graduates in the context of the competency-based approach]. Upravlenie chelovecheskimi resursami. Sbornik nauchnykh trudov. Novosibirsk: Novosibirsk State University of Economics and Management, n. 2, 2016.

MISHCHENKO, L. V. Integrativnaia psikhologiia pologendernogo razvitiia cheloveka: Uchebnoe posobie [Integrative psychology of sex-gender human development: study guide]. Moscow: KNORUS, 2016.

POGREBITSKAIA, M. V. Sistema potrebitelskogo monitoringa vuza [The system of consumer monitoring of a university]. Kachestvo obrazovaniia: menedzhment, dostizheniia, problemy: Materialy VI Mezhdunarodnoi nauchno-metodicheskoi konferentsii. Novosibirsk: Publishing house of the Novosibirsk State Technical University, 2005.

POMELNIKOVA, E. A. Subektnaia pozitsiia budushchego spetsialista k uspeshnoi professionalnoi deiatelnosti kak osnova professionalnogo samoopredeleniia [Subject

RPGE- Revista on line de Política e Gestão Educacional, Araraquara, v. 25, n. esp. 1, p. 638-653, mar. 2021. e-ISSN:1519-9029 
position of a future specialist to successful professional activity as the basis for professional self-determination]. Education, innovations, research as a resource for community development. Collection of materials of the International Scientific and Practical Conference. Cheboksary: Sreda Publishing House LLC, 2017.

\section{RUSANOVA, A. A. Udovletvorennost kak pokazatel kachestva obrazovaniia v} sovremennom vuze (iz opyta konkretnogo sotsiologicheskogo issledovaniia) [Satisfaction as an indicator of education quality in a modern university (from the experience of a specific sociological study)]. Novosibirsk: Novosibirsk State Technical University, 2005.

SHLYKOV, G. P. Sistema menedzhmenta kachestva universiteta [University quality management system]. Moscow: "NTK "Trek” Publishing House, 2008.

\section{SUSHCHENKO, A. D.; KUZNETSOV, P. D.; PECHENKINA, T. E. Izmerenie}

udovletvorennosti vysshim obrazovaniem finansovo uspeshnykh i neuspeshnykh vypusknikov [Measuring satisfaction with higher education among financially successful and unsuccessful university graduates]. Theory and Practice of Social Development, n. 10, p. 30-36, 2019.

UPRAVLENIE KACHESTVOM podgotovki spetsialistov v vysshei shkole: teoriia i praktika: kollekt: Monografiia [Management of the quality of training of specialists in higher education: theory and practice: a collective monograph]. Volgograd: Change, 2008

VASILEVA, E. I. U. Sistemnyi monitoring kachestva obrazovatelnoi sredy vuza [Systemic monitoring of the educational environment of the university (Northern state medical university)]. Universitetskoe upravlenie: praktika i analiz, v. 3, n. 55, p. 24-34, 2008.

VOLOVSKAIA, N. M.; PLIUSNINA, L. K. Vnutrennii sotsiologicheskii monitoring kachestva obrazovatelnoi deiatelnosti vuza [Internal sociological monitoring of the quality of educational activities of a university]. Theory and Practice of Social Development, n. 24, p. 16-18, 2015.

\section{How to reference this article}

AVRAMKOVA, I. S.; ANUFRIEVA, N. I.; KAMYANETS, A. V.; KUZNETSOVA, E. O.; SCHERBAKOVA, A. I. Monitoring studies of university graduates' satisfaction with the quality of education: the main approaches. Revista on line de Política e Gestão Educacional, Araraquara, v. 25, n. esp. 1, p. 638-653, mar. 2021. e-ISSN:1519-9029. DOI: https://doi.org/10.22633/rpge.v25iesp.1.15004

Submitted: 06/11/2020

Required revisions: $18 / 01 / 2021$

Approved: $23 / 02 / 221$

Published: 01/03/2021 